\title{
PENINGKATAN KEMAMPUAN MELATIH LARI SPRINT 100 M, 200 M, DAN 400 M MELALUI KEPELATIHAN PROGRAM LATIHAN PADA PELATIH PPLM PAPUA TAHUN 2009
}

\author{
Sutoro \\ FIK Universitas Cenderawasih Papua (email: sutoro_duin@yahoo.co.id)
}

\begin{abstract}
Abstrak: Peningkatan Kemampuan Melatih Lari Sprint 100 M, 200 M dan 400 M melalui Kepelatihan Program Latihan pada Pelatih PPLM Papua. Penelitian ini bertujuan agar pelatih dan atlet lari sprint menerapkan berbagai model latihan teknik gerakan tungkai dan lengan, memiliki tujuan pembinaan yang terarah dan menerapkan IPTEK keolahragaan. Metode yang digunakan adalah penelitian tindakan kelas dengan rancangan dua siklus. Prosedur penelitiannya: (1) perencanaan, (2) pelaksanaan, (3) pengamatan dan evaluasi, serta (4) analisis dan refleksi. Teknik pengambilan data dengan wawancara, tanya jawab dan pengamatan. Hasil tindakan siklus I disimpulkan bahwa 2 pelatih (28\%) telah menyusun dan mempraktikkan program latihan, model-model latihan teknik tungkai dan lengan, dan IPTEK keolahragaan; 4 pelatih (59\%) belum menyusun dan mempraktikkan program latihan, 5 pelatih $(70 \%)$ tidak menggunakan model-model latihan teknik tungkai dan lengan, dan IPTEK keolahragaan. Hasil tindakan siklus II disimpulkan bahwa semua pelatih $(100 \%)$ telah menyusun dan mempraktikkan program latihan, model-model latihan teknik tungkai dan lengan, serta IPTEK keolahragaan.
\end{abstract}

Kata Kunci: kemampuan melatih lari, sprint 100, 200 dan 400 M, model latihan

Abstract: The Development of Skills to Train the $100 \mathrm{M}, 200 \mathrm{M}$, and $400 \mathrm{M}$ Sprinter through the Coaching Training Program for Central of Education and Training Student of Papua. This study aims at trainers and athletes of sprinter to apply a variety of techniques as training models in the movement feet and arms and also to have the ability to lead and apply Sport Science and Technology. The study used methods of Sports Action with the approach of 2 cycles. The procedure consists of: (1) Action plan, (2) Application of action, (3) Observation and evaluation, (4) Analysis and reflection. The techniques and data gained from: interviews, questioners and observation. The results from action 1 (cycle 1) can be concluded as follow: Two of trainers $(28 \%)$ could be able to submit and apply the techniques of training models, the movements of the feet, legs, arms and hands and also Sports Science and Technology. Four trainers (59\%) could be able to submit and could not practice the training program yet. Five of trainers $(70 \%)$ failed to use the techniques of training models and the techniques to move feet/egs, arms and hands also Sports Science and Technology. Later on the second cycles it is concluded that: All of trainers $(100 \%)$ could be able to submit and 
practice the techniques to move feet/egs, arms hands and also Sports Science and Technology.

Keywords: the skill to train 100 M, 200 M, and 400 M excercise model

\section{PENDAHULUAN}

Pada PON XVII tahun 2008 di Kalimantan Timur (Kaltim) yang lalu, prestasi yang dicapai oleh kontingen Papua mengalami keterpurukan dalam penempatan urutan memperoleh medali masing-masing daerah. Hal itu ditengarai oleh turunnya rangking yang dicapai Papua, yaitu PON XVII Papua menempati urutan ke-11 dari urutan ke-7 sebelumnya pada PON XVI di Palembang tahun 2004 (Laporan Evaluasi Pelaksanaan Pemusatan Latihan/ TC PON XVII dan PON XVII KALTIM Tahun 2008). Keterpurukan prestasi kontingen Papua pada PON XVII di Kaltim tahun 2008 utamanya disebabkan oleh target cabang olahraga (cabor) atletik yang diprediksi memperoleh 8 medali emas, namun faktanya hanya meraih 2 medali emas. Cabor atletik inilah yang merupakan salah satu penyebab menurunnya rangking Papua pada PON XVII. Pada hal andalan atlet Papua berada di nomor sprint seperti: $100 \mathrm{~m}, 200 \mathrm{~m}, 400 \mathrm{~m}, 800 \mathrm{~m}$, estafet $4 \mathrm{X}$ $100 \mathrm{~m}$, dan 4 X $400 \mathrm{~m}$. Tragisnya pada nomor-nomor andalan tersebut Papua hanya mendapatkan 1 medali perak dan 4 medali perunggu (Laporan Evaluasi Pelaksanaan Pemusatan Latihan/ TC PON XVII dan PON XVII KALTIM Tahun 2008). Kondisi tersebut benarbenar di luar prediksi yang diharapkan oleh kontingen Papua pada PON XVII Kaltim.
Dari hasil evaluasi ditemukan permasalahan yang ada di lapangan saat pelaksanaan training central (TC) oleh anggota monitoring Puslatprov (Pusat Latihan Provinsi) Papua di antaranya adalah: kedisiplinan atlet dan pelatih sebagian besar cabor rendah. Banyak pelatih yang tidak mengetahui program latihan dan ada pelatih yang mengetahui program latihan tetapi tidak melaksanakan dengan kesungguhan hati di lapangan. Rekruitmen calon atlet tidak dilakukan sejak dini dan tidak berasal dari klub karena terbatasnya waktu sehingga pemanduan bakat dan pembinaan dini menjadi kendala. Para atlet yang diperhitungkan memperoleh medali, hampir di semua cabang olahraga telah melewati golden age, yang merupakan periode ambang batas bagi seorang atlet berpotensi dan menghasilkan prestasi tertinggi sebagai juara. Motivasi atlet yang berlomba untuk menghadapi lawan relatif tidak cukup dan untuk mencapai prestasi terbaik aspek tersebut harus menjadi bagian dari pembinaan prestasi dan pembentukan mental juara. Selain itu, motivasi untuk menjadi juara terganggu oleh pemikiran tidak cukup besarnya bonus yang dijanjikan untuk sang juara (tidak cukup besarnya insentif bagi seorang atlet), jika dibandingkan dengan daerah lain (Evaluasi Pelaksanaan PON XVII/2008 Kalimantan Timur). 


\section{Program Latihan}

Program latihan adalah suatu rencana latihan yang berisi latihan fisik, teknik, mental dan strategi yang tersusun secara sistematis, terarah, terukur dan berkesinambungan dengan memperhatikan prinsip-prinsip latihan untuk menuju ke puncak prestasi (Peak performance). Hal ini dimaksudkan agar program latihan yang dijalankan mampu memberikan efek yang positif bagi peningkatan kualitas fungsional sistem tubuh. Tujuan penyusunan materi program latihan adalahuntuk meningkatkan kualitas kterampilan, kebugaran otot, dan kebugaran energi olahragawan (Sukadiyanto, 2011: 47). Salah satu tugas penting pelatih adalah menyusun program latihan. Dengan program latihan pelatih dapat melakukan tugasnya secara teratur, sistematis, terencana untuk mencapai sasaran latihan melalui tahap-tahap yang diinginkan. Un- tuk itu, menurut Argasasmita (2007), suatu keharusan bagi pelatih untuk menyusun program latihan yang akan dipergunakan sebagai panduan dalam pelaksanaan tugasnya.

Terdapat 3 (tiga) macam program latihan yakni program latihan jangka panjang (8-12 tahun), jangka menengah (2-7 tahun), dan jangka pendek atau tahunan. Program latihan jangka pendek biasanya diimplementasikan dalam sebuah periodisasi latihan tahunan sebagai ujung tombak dalam program latihan secara keseluruhan, yang dikenal dengan periodisasi dan terbagi menjadi: periode persiapan, periode kompetisi dan periode transisi. Periode persiapan dibagi menjadi dua, yaitu persiapan umum dan persiapan khusus, sedangkan periode kompetisi dibagi menjadi prekompetisi dan kompetisi utama (seperti pada gambar di bawah ini).

Tabel 1. Dasar Periodisasi Latihan

\begin{tabular}{cccc}
\hline \multicolumn{2}{c}{ Persiapan } & Kompetisi & Transisi \\
\hline Pers. Umum & Pers. Khusus & Prekompetisi & Kompetisi Utama \\
\hline & Rincian Program \\
\hline
\end{tabular}

\section{Periode Persiapan}

Periode persiapan adalah awal periode di mana memerlukan waktu yang paling panjang di antara periode yang lain. Pada periode ini unsur volume latihan dikembangkan bergerak dengan persentase semakin naik lebih dahulu daripada unsur intensitas latihan. Volume meningkat dan mencapai puncaknya pada pertengahan persiapan khusus dan kemudian menurun sampai pada periode kompetisi dan transisi.
Intensitas latihan meningkat pelan di bawah garis volume pada persiapan umum. Menurut Argasasmita (2007), pada pertengahan persiapan khusus di mana volume mulai menurun, garis intensitas masih meningkat sehingga menjadi sama dan kemudian lebih tinggi dari garis volume.

Isi latihan pada persiapan umum cenderung berisi mengenai teknik dasar atau perbaikan teknik secara bagian dari kelemahan teknik yang ada pada 
periode kompetisi sebelumnya. Pembinaan kondisi fisik diarahkan untuk pembentukan fisik umum melalui pembinaan otot-otot seluruh tubuh dan daya tahan otot serta cardiovascular. Persiapan umum ini merupakan fase yang mendasari fase-fase selanjutnya (Soeharno, 1978; Argasasmita, 2007). Pada persiapan khusus, isi latihan mulai mengarah pada pembangunan otot khusus sesuai dengan cabang olahraga dan sistem energi yang dominan. Bentuk gerakan kompetisi sudah nampak pada fase ini sehingga atlet sudah dapat mengikuti latih tanding (try out) atau kejuaraan yang tidak penting sebagai sarana evaluasi latihan (Argasasmita, 2007).

\section{Periode Kompetisi}

Pada periode kompetisi volume latihan semakin menurun, namun intensitas latihan meningkat mendekati puncak. Hal ini berarti bahwa latihan berorientasi pada kompetisi yang akan dihadapi. Pada fase prekompetisi, atlet banyak melakukan uji coba sehingga kematangan bertanding meningkat dan dapat meningkatkan kepercayaan diri. Fase ini menjadi pengantar ke kompetisi utama di mana semua kemampuan fisik, teknik, mental dan taktik atlet dimunculkan secara optimal pada kompetisi utama (Argasasmita, 2007).

\section{Periode Transisi}

Periode transisi merupakan periode terpendek, di mana atlet diberi kesempatan untuk melakukan regenerasi dari beban latihan yang telah dilaksanakan selama periode dan fase sebelumnya. Isi latihan pada periode ini biasanya istirahat aktif dengan melakukan kegiatan gerak yang menyenangkan dan bukan menjadi cabang olahraganya. Untuk mengatur volume dan intensitas latihan dapat melakukan dengan garis volume dan intensitas pada periodisasi berikut.

\begin{tabular}{|c|c|c|c|c|}
\hline \multicolumn{2}{|c|}{ Persiapan } & \multicolumn{2}{|c|}{ Kompetisi } & Transisi \\
\hline Pers. Umum & Pers. Khusus & Prekompetisi & Main Kompetisi & \\
\hline
\end{tabular}

Gambar 1. Garis Volume dan Intensitas Latihan (Argasasmita, 2007)

\section{Siklus Mikro}

Siklus mikro adalah bagian dalam periode latihan yang diimplementasikan dalam program latihan mingguan. Pelatih harus mampu untuk menyusun program latihan mingguan/siklus mi- kro ini sesuai dengan periode dalam periodisasi latihan. Dalam diagram periodisasi siklus mikro dapat dinotasikan pada bagian atas periode sebagai berikut. 


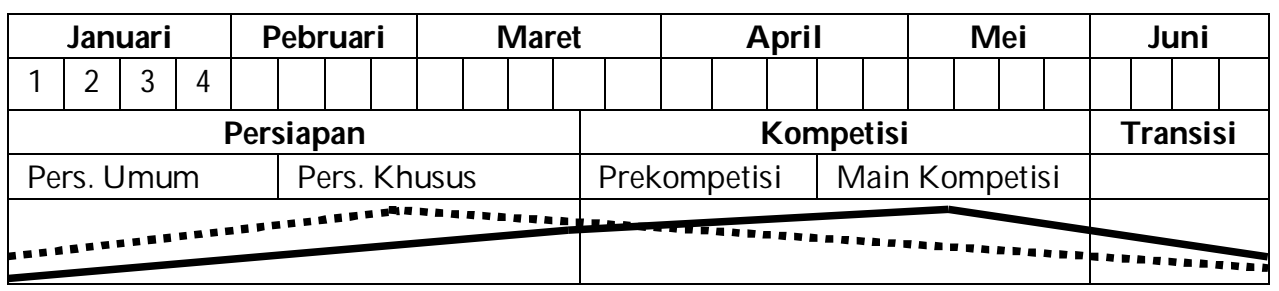

Gambar 2. Periodisasi Dengan Kerangka Waktu (Bulan dan Minggu) (Argasasmita, 2007)

Dari gambar di atas dapat dilihat bulan Januari ada empat minggu yaitu minggu 1-4. Artinya, pada bulan Januari ada 4 siklus mikro. Periode persiapan mulai Januari dan berakhir bulan April minggu kedua. Siklus mikro (program latihan mingguan) terdiri dari sesi latihan (latihan harian). Program latihan mingguan disusun setiap minggu dengan mempertimbangkan berbagai hal. Latihan mingguan untuk menentukan jumlah hari latihan dan sesi latihan (frekuensi latihan). Hal-hal yang perlu dipertimbangkan dalam menyususun program mingguan adalah: (1) usia kronologis dan usia tumbuh serta kembang anak; (2) periode dan fase; dan (3) pengaturan beban latihan.

Usia kronologis dan usia pertumbuhan serta perkembangan anak berkaitan dengan pertumbuhan fisik dan mental serta usia latihan (waktu yang diperlukan untuk berlatih). Semakin cepat pertumbuhan dan perkembangan anak, usia latihan yang semakin lama, hari dan sesi latihan yang diberikan kepada atlet dapat ditingkatkan. Periode dan fase. Untukmenyusun latihan mingguan perlu diketahui periode dan fase latihan mingguan yang disusun. Periode dan fase latihan perlu disesuaikan dengan grafik intensitas dan volume latihannya. Pengaturan beban latihan.
Untuk memberikan beban secara proposional kepada atlet perlu memperhatikan pengaturan beban latihan. Dengan pengaturan beban latihan yang tepat atlet dapat mengadaptasi dan mengalami kompensasi akibat latihan yang dilakukan. Selanjutnya rancangan beban latihan dalam satu minggu tersebut perlu diimplementasikan dalam program latihan mingguan dengan pola yang telah ditentukan dengan menggunakan blangko latihan mingguan (Argasasmita, 2007).

\section{Sesi Latihan}

Sesi (unit) adalah jumlah materi program latihan yang disusun dan yang harus dilakukan dalam satu kali pertemuan (tatap muka) (Sukadiyanto, 2011:32). Unit latihan bisa berupa unit latihan teknik, fisik, mental atau gabungan dari beberapa unit latihan. Beberapa hal yang perlu diperhatikan oleh para pelatih dalam menyusun sesi latihan adalah: (1) penyusunan sesi latihan harus memperhatikan grafik beban latihan pada siklus mikro (latihan mingguan); (2) menentukan tujuan latihan khusus pada sesi tersebut. Tujuan utama latihan teknik dapat berbentuk latihan fisik, teknik atau latihan yang lain. Secara rinci tujuan itu perlu diketahui untuk menentukan bentuk 
latihan yang akan dilaksanakan; dan (3) sesi latihan perlu disusun secara baik agar berjalan secara efektif (Argasasmita, 2007).

Tujuan latihan akan tercapai jika mengikuti prinsip-prinsip latihan. Prinsip latihan merupakan hal-hal yang harus ditaati, dilakukan atau dihindari agar tujuan latihan dapat tercapai sesuai dengan yang diharapkan (Sukadiyanto, 2011:13). Adapun prinsip-prinsip latihan menurut Fox (1988) dan Bompa (1990) adalah: (1) prinsip beban lebih; (2) prinsip beban bertambah; (3) prinsip kekhususan; (4) prinsip individual; dan (5) prinsip pemulihan.

Prinsip beban lebih ditunjukkan untuk peningkatan kualitas dari latihan yang dilakukan. Beban latihan yang diberikan kepada atlet harus melebihi beban yang biasanya diterima dari aktivitas sehari-hari. Hal ini disebabkan karena sistem faal tubuh mampu menyesuaikan diri terhadap stimulus yang diterimanya. Penerapan ini bertujuan untuk mendapatkan efek latihan yang positif terhadap organ-organ tubuh atlet (Brook, 1987 dan Fox, 1988).

Prinsip latihan beban bertambah adalah beban kerja dalam latihan ditingkatkan secara bertahap dan disesuaikan kemampuan fisiologis dan psikologis setiap individu atlet. Ozolin (1971) menyatakan bahwa hasil latihan secara fungsional akan positif bila kapasitas kerja ditingkatkan secara bertahap dalam waktu yang cukup lama. Peningkatan dapat dilaksanakan dengan cara meningkatkan beban, set, repetisi, frekuensi maupun lamanya latihan. Menurut Astrand dan Rodahl (1986) bahwa peningkatan kinerja atlet memerlukan latihan dan penyesuaian dalam waktu yang panjang. Lebih lanjut Hakkinen (1993) menyatakan bahwa peningkatan beban yang tidak sesuai atau sangat tinggi dan mendadak dapat menurunkan kualitas kerja sistem saraf dan dapat menimbulkan cedera.

Prinsip kekhususan adalah latihan untuk satu cabang olahraga, mengarah pada perubahan morfologis dan fungsional yang berkaitan dengan kekhususan olahraga tertentu (Bompa, 1990). Prinsip kekhususan ini meliputi: kelompok otot yang terlatih, pola gerakan yang berhubungan, sistem energi utama dan sudut sendi (Bompa, 1990). Dengan menerapkan prinsip ini tentunya efek latihan yang positif akan diperoleh atlet sehingga pencapaian prestasi bisa lebih maksimal.

Faktor individual harus diperhatikan, karena pada dasarnya setiap individu mempunyai karakteristik yang berbeda, baik secara fisik maupun secara psikologis (Bompa,1990). Dalam hal ini yang harus diperhatikan adalah kapasitas kerja, perkembangan kepribadian, penyesuaian fungsional individu dan kekhususan organisme. Bompa (1990) menyatakan walaupun penerapan prinsip ini sangat sulit dan membutuhkan perhatian dan kemampuan lebih dari seorang pelatih.

Aktivitas yang dilakukan setelah melaksanakan latihan biasanya bertujuan untuk pemulihan. Pemulihan akan mengembilikan kondisi tubuh pada keadaan sebelum beraktivitas. Pemulihan bertujuan memuliskan cadangan energi, oksigen dan membuang asam laktat dari darah dan otot. Bentuk kegiatan selama pemulihan dapat dilakukan 
dengan cara istirahat pasif dan aktif (pergangan dan aktivitas ringan jogging) (Fox, 1988; Bompa, 1990; Willmore, 1994). Diharapkan dengan menerapkan prinsip dasar latihan dalam program latihan dapat member efek positif bagi peningkatan kualitas fungsional sistem tubuh.

\section{Pembinaan Atlet}

Atlet adalah individu yang menjadi subyek dan sekaligus objek dalam proses suatu latihan maupun suatu pembinaan dalam cabang olahraga tertentu. Atlet merupakan faktor yang paling utama dalam pencapaian suatu prestasi olahraga. Contoh yang terjadi di Papua Barat, seorang pelempar lembing ( $Y u-$ lius Morin) dapat menjuarai PON XVII di Kaltim tahun 2008 tanpa seorang pelatih dan atlet tersebut terbiasa latihan sendiri dengan cara melempar kelapa di pohon. Atlet adalah manusia yang memiliki kompleksitas, maka dalam memilih atlet perlu diperhatikan halhal sebagai berikut: Watak kepribadian (mental), postur tubuh (fisik), kecerdasan (EQ) dan kesehatan (Evaluasi PON XVII/2008 Kalimantan Timur, 2008).

Pembinaan atlet adalah proses pendewasaan atlet baik melalui pelatihan maupun non pelatihan yang dilakukan oleh klub, pengprov cabang olahraga maupun pengurus olahraga yang berada di atasnya dalam waktu yang lama untuk memperoleh prestasi atlet yang maksimal dan baik (Evaluasi PON XVII/2008 Kalimantan Timur, 2008). Proses pembinaan atlet dilakukan secara hirarkis sejak masih usia muda sampai dewasa, dimulai dari pemasalan, pembibitan, dan pembinaan secara progresif dan berkelanjutan. Proses rekruitmen calon atlet usia dini di Papua dilakukan melalui pemanduan bakat, di antaranya melalui tes anthropometri yang dilakukan oleh Dinas Pendidikan dan Pengajaran bekerjasama dengan klub atau Pengcab/Pengprov yang difasilitasi oleh KONI Papua. Setelah diperoleh bibit atlet yang potensial sesuai dengan cabang olahraga, maka proses pembinaan (latihan) diperlukan waktu 8-12 tahun di klub atau sekolah olahraga. Seorang atlet yang berlatih selama 8-12 tahun secara rutin, bertahap dan kontinyu, akan memasuki usia emas (Golden Age) jika dalam perjalanan berlatih/dibina tidak mengalami gangguan yang cukup berarti (Evaluasi PON XVII/2008 Kalimantan Timur, 2008).

Di Papua, dari 43 Pengprov cabang olahraga yang ada di lingkungan Koni Papua terdapat 3 Pengprov yang sudah melakukan pembinaan atlet secara baik berdasarkan evaluasi Koni Provinsi Papua, yaitu: sepak bola (PSSI), bola basket (PERBASI), bola voli (PBVSI), dan dayung (PODSI). Cabang olahraga lain yang bersifat individu, seperti bela diri (pencak silat, karate, kempo, taekwondo), tinju, renang, balap sepeda dan olahraga beregu seperti tenis meja, tenis lapangan, bulu tangkis soft ball, proses pembinaannya sangat memprihatikan. Selain itu, pembinaan atlet oleh PASI Papua masih tidak menentu, baik itu dari regenerasi atlet, latihan atlet maupun pelatih yang ada (Evaluasi PON XVII/2008 Kalimantan Timur, 2008). Faktanya manfaat Pembinaan atlet adalah untuk membina dan mengembangkan bakat atlet ke mutu 
prestasi maksimal dengan biaya yang secara efektif dan dalam waktu yang se-efisien mungkin. Oleh karena itu, sasaran latihan adalah untuk meningkatkan kemampuan dan kesiapan olahragawan dalam mencapai prestasi (Sukadiyanto, 2011: 8).

\section{Iptek Olahraga}

Hawkey (1991) menyatakan bahwa ilmu pengetahuan olahraga adalah penerapan gagasan ilmiah terhadap berbagai aktivitas olahraga. Ilmu pengetahuan keolahragaan adalah pengetahuan yang sistematis dan terorganisasi tentang fenomena keolahragaan yang dibangun melalui sistem pendekatan ilmiah. Teknologi keolahragaan adalah cara-cara dan atau alat yang digunakan untuk mempermudah dalam melakukan kegiatan olahraga. IPTEK keolahragaan adalah pengetahuan dan teknologiyang teruji yang keberadaannya diperlukan dalam pengembangan keolahragaan (Furqon, 2006). Bompa (1990) menyatakan bahwa sebagian sumber pengetahuan diarahkan pada peningkatan dan pemahaman pengaruh latihan terhadap tubuh. Oleh karena itu, latihan merupakan unsur utama kegiatan

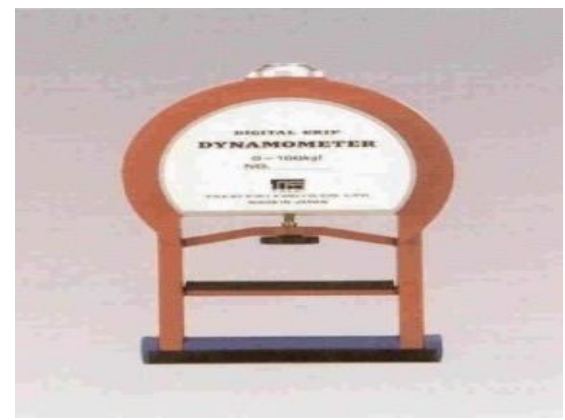

Grip Dynamometer ilmu pengetahuan olahraga. Teori dan metodologi sebagai ilmu latihan, memiliki subjek sendiri dalam riset terapan yaitu atlet, memberikan sumber informasi yang luas bagi pelatih maupun ilmuwan olahraga (Furqon, 2006).

Ilmu pengetahuan yang mendukung untuk memperkaya bidang pengetahuan teori dan metodologi latihan adalah: anatomi-fisiologi, biomekanik, statistik, tes dan pengukuran, kedokteran olahraga, psikologi, belajar gerak, pedagogi, gizi, sejarah, dan sosiologi (Furqon, 2006). Jadi, seorang pelatih selain mengusai ilmu kepelatihan sebagai dasar dalam melatih juga harus memahami ilmu tersebut.

Teknologi olahraga dapat berupa peralatan yang modern untuk mengetahui dan mempermudah dalam tes dan pengukuran secara valid dan reliabel. Contohnya alat grip dan back leg dynamometer untuk mengukur kekuatan otot tangan, tungkai dan punggung, spirometer alat untuk mengetahui kapasitas vital paru, biomechanical motion analysis alat untuk mengetahui analisis gerakan tubuh (seperti contoh gambar di bawah ini).

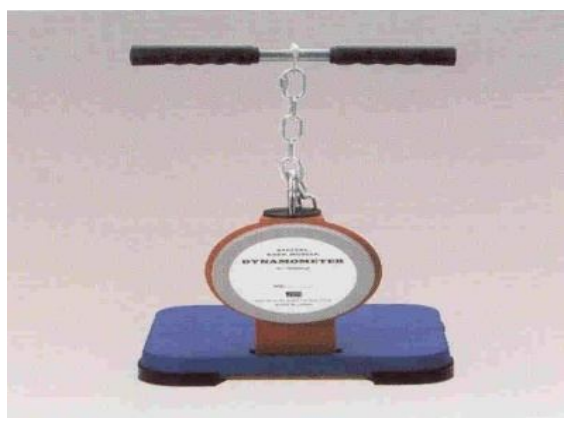

Black Leg Dynamometer Gambar 4. Teknologi Grip Dynamometer dan Black Leg Dynamometer 


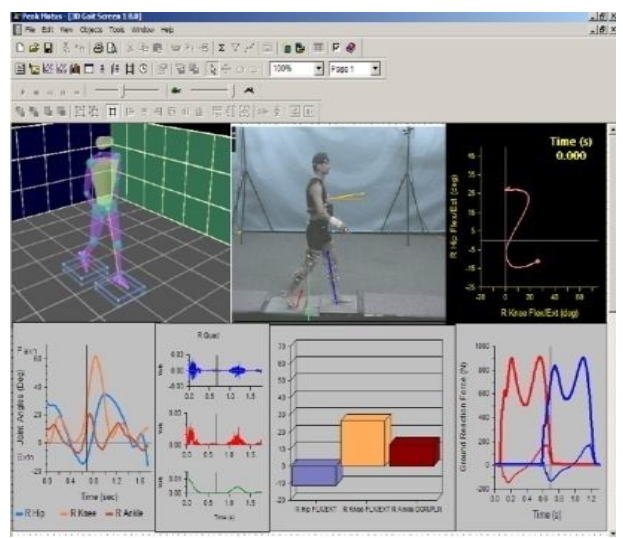

Biomechanical Motion Analysis

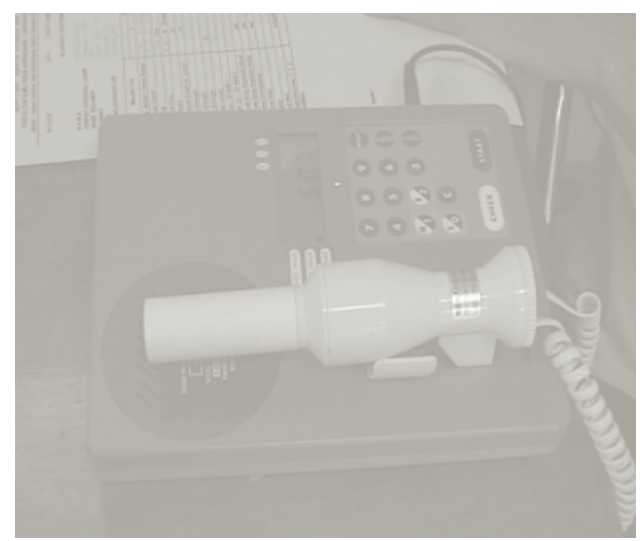

Spirometer

Gambar 5. Teknologi Biomechanical Motion Analysis dan Spirometer

Guna IPTEK olahraga adalah untuk: (1) mendapatkan data yang akurat untuk kemampuan dasar seseorang atlet; (2) menyusun suatu program latihan yang spesifik bagi suatu cabang olahraga; (3) membuat program latihan yang spesifik sesuai tingkat kemampuan fisik seorang atlet; (4) monitoring dan Evaluasi terhadap program latihan yang telah dilakukan; dan (5) peningkatan kemampuan seorang atlet baik dari segi fisik, teknik dan mental untuk akhirnya mencapai prestasi yang maksimal.

\section{METODE}

Penelitian ini menggunakan metode penelitian tindakan kelas/PTK (Classroom Action Research/CAR). Bentuk desain penelitian diadopsi dari Kemmis \& Taggart (1988) seperti terlihat pada Gambar 6.

Model ini pada hakikatnya merupakan perangkat atau untaian dengan satu perangkat terdiri dari empat komponen, yaitu perencanaan, tindakan, pengamatan dan refleksi. Untaian- untaian tersebut sebagai suatu siklus. Oleh karena itu, pengertian siklus di sini adalah putaran kegiatan yang terdiri dari perencanaan, tindakan, observasi dan refleksi.

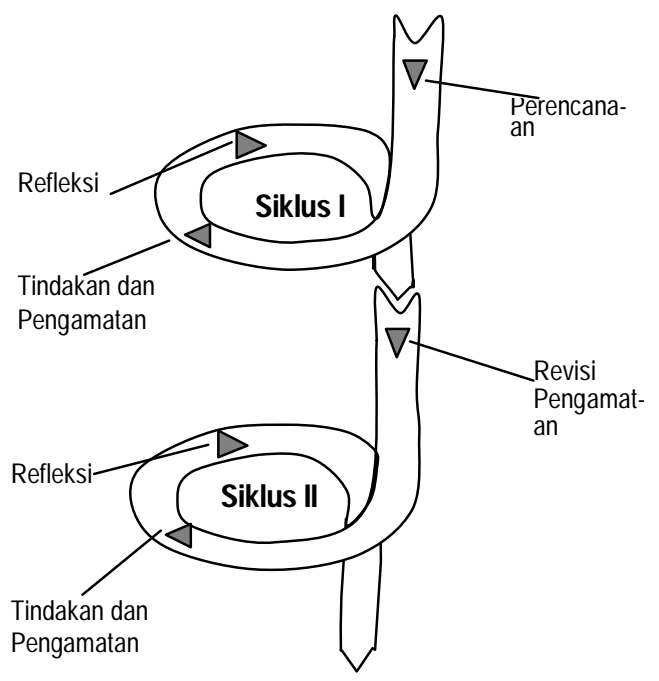

Gambar 6. Siklus Penelitian Tindakan Kelas

Tempat penelitian di Stadion Mahacendera Uncen Jayapura Provinsi Papua dan waktu penelitian dilaksanakan pada April sampai Juli 2009. 
Karena objeknya sesuatu yang aktif dan dapat dikenai aktivitas, bukan objek tanpa gerak/diam, yaitu para atlet, pelatih dan materi pelatihan (program latihan, pembinaan atlet dan IPTEK keolahragaan) PPLM Papua.

Penelitian ini merupakan penelitian tindakan yang dilakukan untuk meningkatkan kemampuan pelatih dan prestasi atlet pada nomor lari sprint 100 m, $200 \mathrm{~m}$ dan $400 \mathrm{~m}$. Proses tindakan dilaksanakan secara prosedur yang terdiri dari: (1) perencanaan tindakan; (2) pelaksanaan tindakan; (3) pengamatan dan evaluasi; serta (4) analisis dan refleksi. Metode penelitian aplikasi ini menggunakan metode tindakan dengan pendekatan rancangan siklus1 dan siklus 2 .

\section{Perencanaan Tindakan}

Pada tahap ini, peneliti dengan pelatih secara kolaboratif mengadakan kegiatan (1) mengidentifikasi dan mengkaji tingkat pemahaman proses para pelatih dalam melatih atletik pada nomor lari sprint 100 m, $200 \mathrm{~m}$ dan 400 m; (2) mengidentifikasi faktor-faktor kesulitan dan hambatan para pelatih dalam proses melatih atletik pada nomor lari sprint 100 m, 200 m, dan 400 m; (3) mengidentifikasi pemahaman dan pengaplikasian IPTEK keolahragaan para pelatih.

\section{Pelaksanaan Tindakan \\ Perencanaan Tindakan I}

Dalam tahap perencanaan tindakan ini, peran peneliti adalah melakukan kegiatan/tindakan eksplorasi, yakni berusaha menggali pemahaman awal para pelatih terhadap program latihan dan
IPTEK keolahragaan. Adapun caranya dengan memberikan kesempatan kepada para pelatih untuk mendefinisikan program latihan dan penerapan IPTEK keolahragaan serta pengalamannya sebagai pelatih.

\section{Pelaksanaan Tindakan I}

Tahap pelaksanaan tindakan pada minggu pertama bulan Juni 2009, yaitu pada hari Senin, Rabu dan Jumat setiap jam 15.30 - 17.30 WIT. Tindakan yang dilakukan pada siklus I ini adalah melaksanakan aktivitas ekploratif (penelusuran) melalui pengamatan dan diskusi antara peneliti dan pelatih yang sedang melakukan proses latihan terhadap para atlet.

\section{Analisis dan Refleksi Tindakan I}

Pada tahap ini peneliti secara kolaboratif dengan pelatih mengadakan kegiatan (1) identifikasi faktor-faktor kekurangpahaman pelatih terhadap program latihan; (2) merekam banyaknya model-model melatih teknik; (3) mengungkap apakah pelatih telah menerapkan IPTEK keolahragaan?

Dari 6 (enam) pelatih, semuanya telahmengenal/mengerti program latihan, namun semuanya dalam melatih jarang (tidak) membuat program latihan sehingga di lapangan saat melatih hanya mengandalkan hafalan apa yang ada di angan-angan (kepala) pelatih. Setelah 3 xhari latihan, ternyata penerapan model latihan teknik tungkai dan lengan masih sangat terbatas (minim), sehingga masih banyak atlet yang gerakan tungkai dan lengan masih salah. Demikan juga penerapan IPTEK keolahragaan yang masih sangat terbatas 
(minim). Berdasarkan temuan tersebut, peneliti merencanakan adanya siklus II yang berisi model latihan teknik tungkai dan lengan serta penerapan IPTEK keolahragaan yang cukup banyak dan bervariasi.

\section{Tindakan II}

\section{Perencanaan Tindakan II}

Berdasarkan hasil pada pelaksanaan tindakan I, diketahui beberapa aspek yang harus diperbaiki (ditambah). Dari hasil evaluasi dan refleksi pada tindakan I, beberapa aspek tersebut antara lain (1) model latihan teknik tungkai dan lengan masih terbatas; (2) belum dilakukan penerapan IPTEK keolahragaan saat latihan. Berdasarkan hasil analisis dan refleksi tindakan I tersebut, maka untuk tindakan II direncanakan akan melakukan penambahan jumlah model latihan teknik tungkai dan lengan serta lebih banyak lagi penerapan IPTEK keolahragaan.

\section{Pelaksanaan Tindakan II}

Tindakan II ini dilaksanakan pada minggu keempat bulan Juni 2009 pada hari Senin, Rabu dan Jumat setiap jam 15.30 - 17.30 WIT. Tindakan yang dilakukan pada siklus II adalah melaksanakan aktivitas intervensi menambah jumlah model latihan teknik tungkai dan lengan serta lebih banyak lagi penerapan IPTEK keolahragaan.

\section{Analisis dan Refleksi Tindakan II}

Dari pelaksanaan tindakan II, peneliti beserta pelatih melakukan analisis dan refleksi hasil dari tindakan II. Berdasarkan hasil dari tindakan II diketahui bahwa kemampuan melak- sanakan program latihan di lapangan meningkat, penguasaan model latihan teknik tungkai dan lengan meningkat, dan penerapan IPTEK keolahragaan benar-benar dilaksanakan.

\section{Teknik Pengumpulan Data}

Teknik pengumpulan data dalam penelitian tindakan olahraga ini menggunakan wawancara/interview, tanya jawab dan pengamatan.

\section{HASIL}

Dari hasil diskusi/tanya jawab pada saat pertemuan yang merupakan kegiatan eksploratif untuk menggugah para pelatih mengenai tiga aspek latihan, yaitu: (1) pemahaman program latihan; (2) model latihan teknik tungkai danlengan;serta (3) menerapkan IPTEK keolahragaan. Dari hasil pertanyaan 3 (tiga) aspek di atas, ternyata semua pelatih telah mengenal dan mengerti, namun dalam menyusun dan menerapkan 3 (tiga) aspek di atas di lapangan baru dilakukan oleh $1-2$ pelatih. Jawaban dari para pelatih mengenai 3 (tiga) aspek di atas adalah sebagai berikut. (1) Drs. Ismail Rumbiak: telah mengenal dan mengerti serta menyusun dan mempraktikkan di lapangan terhadap 3 (tiga) aspek di atas. (2) Kurdi, S.Pd: telah mengenal dan mengerti serta menyusun dan mempraktikkan di lapangan terhadap 3 (tiga) aspek di atas. (3) Philipus M, S.Pd: telah mengenal dan mengerti, namun belum pernah menyusun dan mempraktikkan di lapangan terhadap 3 (tiga) aspek di atas. (4) Ferry Wakano, S.Pd: telah mengenal dan mengerti, namun belum pernah menyusun dan mempraktikkan 
di lapangan terhadap 3 (tiga) aspek di atas. (5) Darius Kafiar: telah mengenal dan mengerti, namun belum pernah menyusun dan mempraktikkan di lapangan terhadap 3 (tiga) aspek di atas. (6) Indra Saputra: telah mengenal dan mengerti, namun belum pernah menyusun dan mempraktikkan di lapangan terhadap 3 (tiga) aspek di atas. (7) Subiyanto, MT: telah mengenal dan mengerti, namun belum pernah menyusun dan mempraktikkan di lapangan terhadap 3 (tiga) aspek di atas.

\section{Paparan Hasil Tindakan}

\section{Hasil Tindakan I}

Hasil tindakan dalam hal ini dibagi dua; (1) proses pelaksanaan tindakan; dan (2) hasil tindakan. Berdasarkan pengamatan peneliti proses pelaksanaan tindakan berjalan lancar dan baik. Hasil tindakan I (siklus I) berdasarkan dokumen yang ada dan pengamatan peneliti adalah sebagai berikut. (1) Drs. Ismail Rumbiak: ada program latihan, ada model latihan teknik tungkai dan lengan serta IPTEK keolahragaan yang dipraktikkan di lapangan. (2) Kurdi, S.Pd: ada program latihan, ada model latihan teknik tungkai dan lengan serta IPTEK keolahragaan yang dipraktikkan di lapangan. (3) Philipus M, S.Pd: ada program latihan, tidak ada model latihan teknik tungkai dan lengan serta tidak ada IPTEK keolahragaan, yang dipraktikkan di lapangan adalah program latihan dan apa yang ada dipikiran (angan-angan) untuk model latihan teknik tungkai dan lengan serta tidak ada IPTEK keolahragaan. (4) Ferry Wakano, S.Pd: tidak ada program latihan, tidak ada model latihan teknik tungkai dan lengan serta tidak ada IPTEK keolahragaan, yang dipraktikkan di lapangan apa yang ada dipikiran (angan-angan). (5) Darius Kafiar: tidak ada program latihan, tidak ada model latihan teknik kaki dan tangan serta tidak ada IPTEK keolahragaan, yang dipraktikkan di lapangan apa yang ada dipikiran (angan-angan). (6) Indra Saputra: tidak ada program latihan, tidak ada model latihan teknik tungkai dan lengan serta tidak ada IPTEK keolahragaan, yang dipraktikkan di lapangan apa yang ada dipikiran (angan-angan). (7) Subiyanto, MT: tidak ada program latihan, tidak ada model latihan teknik tungkai dan lengan serta tidak ada IPTEK keolahragaan, yang dipraktikkan di lapangan apa yang ada dipikiran (angan-angan).

Berdasarkan hasil tindakan di atas, ternyata 2 (dua) pelatih telah menyusun dan mempraktikkan program latihan, model latihan teknik tungkai dan lengan, dan IPTEK keolahragaan. Hal ini dapat dibuktikan oleh pelatih yang sudah memiliki program latihan dan dipraktikkan di lapangan serta menggunakan banyak pola latihan teknik gerakan tungkai dan lengan. Selanjutnya, 4 (empat) (59\%) pelatih belum menyusun dan mempraktikkan program latihan, dan 5 (lima) (70\%) pelatih tidak menggunakan model latihan teknik tungkai dan lengan, dan IPTEK keolahragaan. Hal ini dapat dibuktikan oleh pelatih yang tidak memiliki program latihan yang untuk dipraktikkan di lapangan serta pola latihan teknik gerakan tungkai dan lengan yang digunakan sangat terbatas (minim). 


\section{Temuan Masalah Pada Tindakan I}

Masalah-masalah yang ditemukan pada tindakan I adalah para pelatih dalam melatih atlet; (1) masih terdapat 4 (empat) $(59 \%)$ orang pelatih yang tidak terbiasa menyusun dasar program latihan; (2) masih terdapat 5 (lima) $(70 \%)$ orang pelatih yang tidak menggunakan model latihan teknik tungkai dan lengan; dan (3) masih terdapat 5 (lima) $(70 \%)$ orang pelatih yang tidak menerapkan IPTEK keolahragaan.

\section{Hasil Tindakan II}

Hasil tindakan siklus II, tetap dibagi dua, (1)proses pelaksanaan tindakan; dan (2) hasil tindakan. Berdasarkan pengamatan peneliti proses pelaksanaan tindakan siklus II berjalan lancar dan baik. Hasil tindakan siklus II berdasarkan dokumen yang ada dan pengamatan peneliti, sebagai berikut. (1) Drs. Ismail Rumbiak: ada program latihan, ada model latihan teknik tungkai dan lengan serta IPTEK keolahragaan yang dipraktikkan di lapangan. (2)

Kurdi, S.Pd.: ada program latihan, ada model latihan teknik tungkai dan lengan serta IPTEK keolahragaan yang dipraktikkan di lapangan. (3) Philipus M, S.Pd.: ada program latihan, ada model latihan teknik tungkai dan lengan serta ada IPTEK keolahragaan, yang dipraktikkan di 1 a p a n g a n. (4) Ferry Wakano, S.Pd.: ada program latihan, ada model latihan teknik tungkai dan lengan serta ada IPTEK keolahragaan, yang dipraktikkan di lapangan. (5) Darius Kafiar: ada program latihan, ada model latihan teknik tungkai dan lengan serta ada IPTEK keolahragaan, yang dipraktikkan di lapangan. (6)
Indra Saputra: ada program latihan, ada model latihan teknik tungkai dan lengan serta ada IPTEK keolahragaan, yang dipraktikkan di lapangan. (7) Subiyanto, MT.: ada program latihan, ada model latihan teknik tungkai dan lengan serta ada IPTEK keolahragaan, yang dipraktikkan di lapangan.

Semua pelatih telah menyusun dan mempraktikkan program latihan, model latihan teknik tungkai dan lengan, dan IPTEK keolahragaan. Hal ini terbukti semua pelatih telah memiliki program latihan dan dipraktikkan di lapangan serta menggunakan banyak pola latihan teknik gerakan tangan dan menerapkan IPTEK keolahragaan. Jadi, 7 (tujuh) (100\%) pelatih telah menyusun dan mempraktikkan program latihan, serta 7 (tujuh) (100\%) pelatih telah menggunakan model-model latihan teknik tungkai dan tangan/lengan, dan IPTEK keolahragaan.

\section{Temuan Masalah Pada Tindakan II}

Masalah yang ditemukan pada tindakan II adalah para pelatih: (1) Dalam memperbaiki teknik gerakan tungkai atau lengan sudah terlanjur lama salah sehingga mengalami kesulitan dan memerlukan proses waktu yang lama. (2) Untuk perekrutan atlet baru pada nomor-nomor atletik mengalami kesulitan sehingga pada akhirnya yang dilatih hanya atlet itu saja.

\section{PEMBAHASAN}

\section{Tindakan I}

Pembahasan pada tindakan I pada siklus I terdapat 2 (dua) pelatih yakni Drs. Ismail Rumbiak, M.Kes. dan Kurdi, S.Pd. yang telah mempraktikkan 
3 (tiga) aspek (program latihan, model latihan tungkai dan lengan serta menerapkan IPTEK olahraga). Hal ini memang dua pelatih tersebut telah banyak pengalaman menjadi pelatih maupun mengikuti pelatihan daerah dan nasional baik pada cabang olahraga sepakbola maupun atletik. Selain itu ada usaha atau kemauan dari dua pelatih tersebut untuk mempraktikkan 3 (tiga) aspek di atas.

Untuk2(dua)pelatih, yaitu: Philipus M, S.Pd. dan Ferry Wakano, S.Pd tidak mempraktikkan 3 (tiga) aspek (program latihan, model latihan tungkai dan lengan serta menerapkan IPTEK olahraga). Sebenarnya, dua pelatih tersebut telah banyak pengalaman menjadi pelatih maupun mengikuti pelatihan daerah dan nasional, namun usaha atau kemauan kedua pelatih tersebut tidak ada sehingga melatih hanya ituitu saja dan program latihan ada di pikiran saja (angan-angan).

Selanjutnya 3 (tiga) pelatih, yakni Darius Kafiar, S.Pd., Indra Saputra, S.Pd. dan Subiyanto, MT tidak mempraktikkan 3 (tiga) aspek (program latihan, model latihan tungkai dan lengan serta menerapkan IPTEK olahraga). Memang tiga pelatih tersebut masih belum banyak pengalaman menjadi pelatih maupun mengikuti pelatihan daerah dan nasional.

\section{Tindakan II}

Pembahasan pada tindakan II siklus II terdapat 2 (dua) pelatih yaitu Philipus M, S.Pd. dan Ferry Wakano, S.Pd. yang sebenarnya banyak pengalaman menjadi pelatih maupun mengikuti pelatihan daerah dan na- sional, namun usaha atau kemauan dari kedua pelatih tersebut kurang semangat, maka pada pertemuan pertama siklus ke-II peneliti mencoba mendorong dan menasehati kepada dua pelatih tersebut dalam melatih atletnya untuk selalu mempersiapkan diri, agar dinilai orang lain atau pengurus sebagai pelatih yang terkenal dan profesional yang pada gilirannya akan menyesuaikan honornya.

Selanjutnya 3 (tiga) pelatih yakni Darius Kafiar, S.Pd., Indra Saputra, S.Pd. dan Subiyanto, MT yang belum mempraktikkan 3 (tiga) aspek (program latihan, model-model latihan tangan dan kaki serta menerapkan IPTEK olahraga). Pada pertemuan pertama siklus ke-II Peneliti juga memberikan arahan dan dorongan kepada tiga pelatih yang masih muda, bahkan buku, makalah serta CD terkait dengan ilmu kepelatihan, agar menjadi pelatih yang profesional yang membawa atletnya mencapai prestasi puncak baik secara nasional maupun internasional.

\section{PENUTUP}

\section{Kesimpulan}

Dari hasil dan pembahasan pada tindakan siklus I, disimpulkan: ada 2 (Dua) pelatih (28\%) telah menyusun dan mempraktikkan program latihan, model latihan teknik tungkai dan lengan, serta IPTEK keolahragaan. Ada 4 (Empat) pelatih (59\%) belum menyusun dan mempraktikkan program latihan. Ada 5 (Lima) pelatih $(70 \%)$ tidak menggunakan model latihan teknik tungkai dan lengan, dan IPTEK keolahragaan. Berdasarkan hasil dan pembahasan pada tindakan siklus II di- 
simpulkan: Semua pelatih (100\%) telah menyusun dan mempraktikkan program latihan, model latihan teknik tungkai dan lengan, serta IPTEK keolahragaan.

\section{Saran}

Saran yang disampaikan adalah PTK ini perlu dilanjutkan untuk meningkatkan pembinaan atlet. Selain itu, melalui PTK dapat mempopulerkan nomor-nomor cabang olahraga atletik di Papua.

\section{UCAPAN TERIMA KASIH}

Artikel ini tidak akan terbit tanpa bantuan dari berbagai pihak. Oleh karena itu, izinkanlah penulis mengucapkan terima kasih kepada Redaktur Jurnal Cakrawala Pendidikan yang telah memberi input dalam memperbaiki artikel ini. Terima kasih juga penulis sampaikan kepada Staf Jurnal Cakrawala Pendidikan Universitas Negeri Yogyakarta.

\section{DAFTAR PUSTAKA}

Argasasmita, Husein. 2007. Teori Kepelatihan Dasar: Program Latihan. Jakarta: Kementerian Negara Pemuda dan Olahraga.

Asisten Deputi Iptek Olahraga Deputi Peningkatan Prestasi dan Iptek Olahraga Kemennegpora. 2007. Pedoman Penyusunan Proposal dan Laporan Penelitian Pemetaan Olahraga Unggulan Daerah: Jakarta: Asdep IPTEK.

Astrand, P. O and Rodahl, K. 1986. Texbook of Work Physiology. Phy- siological Basis of Exercise. $3^{\text {rd }}$ edition, New York: McGraw Hill Book Company.

Azwar, Saifuddin. 1998. Metode Penelitian (Cetakan I). Yogyakarta: Pustaka Pelajar.

Bompa, Tudor, O. 1990. Theory and Methodology of Training. $2^{\text {nd }}$ Edition, Dubugue, Iowa: Kendall and Hunt Publishing Company.

BPS-Dirjen Olahraga Depnas. 2004. Indikator Olahraga Indonesia. Jakarta: BPS-Dirjen Olahraga.

Brook G. A and Fahey T. D. 1987. Exercise Physiology: Human Bioenergenics and its Applications. New York: John Willey \& Sins.

Deputi Peningkatan Prestasi dan IPTEK Olahraga, Kementerian Negara Pemuda dan Olahraga, 2008. Laboratory Sports Equipment. Jakarta: Deputi IV Kemenpora.

Fox E. L; Bower R. W and Foss M. L. 1988. The Physiological Basis of Physical Education and Athletics. $4^{\text {th }}$ edition, New York: Saunders College Publishing.

Furqon M. H. 2006. Pengembangan dan Pemanfaatan IPTEK Keolahragaan. Semarang: Drahara Prize.

Hakkinen K. 1993. "Neuromuscular Fatique and Recovery in Male and Female Athlete During Heavy Resisten Exercise". International Journal Sport Medicine. 
Kemmis, S. S and McTaggart, R. 1988. The Action Research Planner. Victoria: Deakin University Press.

Koni Provinsi Papua. 2008. Laporan Evaluasi Pelaksanaan Pemusatan Latihan/TC PON XVII dan PON XVII KALTIM. Papua: PT. Horison Jayapura.

2008. Evaluasi pelaksanaan PON XVII/2008 Kalimantan Timur. Papua: PT. Horison Jayapura.

. 2006. Rencana Strategi Pembinaan Olahraga Provinsi Papua Tahun 2006 - 2010. Papua: PT Horison Jayapura.

Maksum, Ali dkk. 2004. Pengkajian Sport Development Index. Jakarta: Kerja- sama Proyek Pengembangan dan Kesrasian Kebijakan Olahraga Dirjen Olahraga Depnas dengan Pusat Studi Olahraga Lemlit Unesa Surabaya.

Sukadiyanto. 2011. Pengantar teori dan metodologi melatih fisik. Bandung: Lubuk Agung.

Ozolin N, 1971. How to improve speed. The Article Scientific Foundation of Coaching. Philadelphia: Human Kinetics Publisher.

Willmore J. and Cosstill D. 1994. Physiology of Sport and Exercise. Champaign, Il.: Human Kinetics. 